\title{
Frugivory and seed dispersal in the Galápagos: what is the state of the art?
}

\author{
Ruben HELENO, ${ }^{1,5}$ Stephen BLAKE, ${ }^{4}$ Patricia JARAMILlO,${ }^{5}$ Anna TRAVESET, ${ }^{1}$ Pablo VARGAS ${ }^{2}$ \\ and Manuel NOGALES ${ }^{3}$ \\ ${ }^{1}$ Mediterranean Institute of Advanced Studies (CSIC-UIB), Terrestrial Ecology Group, Mallorca, Balearic Islands, ${ }^{2}$ Royal Botanical \\ Garden Madrid (CSIC-RJB), Madrid, ${ }^{3}$ Island Ecology and Evolution Research Group (CSIC-IPNA), Tenerife, Canary Islands, Spain, \\ ${ }^{4}$ Max Planck Institute for Ornithology, Vogelwarte Radolfzell, Radolfzell, Germany and ${ }^{5}$ Charles Darwin Foundation, Puerto Ayora, \\ Santa Cruz, Galapagos, Quito, Ecuador
}

\begin{abstract}
The Galápagos are considered a model oceanic archipelago, with unique flora and fauna currently threatened by alien invasive species. Seed dispersal is an important ecosystem function with consequences for plant population dynamics and vegetation structure. Hence, understanding the seed dispersal abilities of the assemblages of frugivores will inform scientists and managers of the dynamics of plant invasions and improve management planning. Here we provide the first comprehensive review of published information on frugivory and animal seed dispersal in the Galápagos. We collected data from a variety of sources, including notes of the first naturalist expeditions, gray literature available only in Galápagos collections, and peer-reviewed journal articles. Plant-animal frugivorous interactions were retrieved from 43 studies and compiled into an interaction matrix describing 366 unique interactions. Most studies focused on fruit consumption as a driving force for natural selection, but seed fate was seldom considered. Although most (71\%) of the interactions involved native plants, more than one-quarter (28\%) involved introduced species. Interactions involving birds are considerably more common than those of reptiles and mammals, probably reflecting a research bias towards birds. Despite the historical importance of the archipelago as the laboratory for evolutionary and ecological research, understanding of its seed dispersal systems is limited. We end the review by suggesting 3 priority areas of research on frugivory and seed dispersal in the Galápagos: (i) target research to close knowledge gaps; (ii) the use of a network approach to frame seed dispersal at the community level; and (iii) evaluation of the effect of seed dispersal as a selective pressure acting upon plants and frugivores. Finally, the output of this research has to be properly delivered to the Galápagos National Park Services to help increase management effectiveness.
\end{abstract}

Key words: conservation planning, oceanic islands, plant invasions, plant-animal interaction, seed predation.

Correspondence: Ruben Heleno, Mediterranean Institute of Advanced Studies (CSIC-UIB), 07190 Esporles, Mallorca, Balearic Islands, Spain.

Email: ruben_huttel@hotmail.com

\section{INTRODUCTION}

For sessile organisms, such as plants, for which seeds usually represent the only mobile stage, seed dispersal is a key service that increases the likelihood of seeds surviving and becoming established adults (Ridley 1930; Van 
der Pijl 1982; Nathan \& Muller-Landau 2000). Seed dispersal allows plants to occupy newly available niches, avoid competition, find suitable physical conditions for the germination of seeds, expand their area of distribution, and escape high mortality rates close to the parent plant due to shading or a high abundance of natural enemies (Janzen 1971; Howe \& Smallwood 1982). By directly dispersing seeds to favorable recruitment sites (Wenny \& Levey 1998) or by virtue of the treatment offered to ingested seeds (Verdú \& Traveset 2004; Traveset et al. 2007), animals play an important role as seed dispersers for many plants (Levey et al. 2002; Dennis et al. 2007). Three classes of vertebrates assume particular relevance as seed dispersers, namely reptiles, birds, and mammals (Stiles 2000). Although birds and mammals are important in continental systems, birds and reptiles have a more significant role on islands, at least on those located at tropical and subtropical latitudes (Olesen \& Valido 2003; KaiserBunbury et al. 2010).

Seed dispersal communities around the globe are being altered by many factors, including pesticide poisoning, hunting, habitat fragmentation, and biological invasions. The likely consequences of such disruptions include a reduction in the diversity of mutualistic species and changes in the densities of survivors (Bond 1994). Given the global scale of lost and degraded habitats, understanding the processes that dictate the movement of seeds (and therefore plants) between disturbed and pristine areas could prove crucial for effective conservation programs.

Despite their poverty in terms of the absolute number of species (MacArthur \& Wilson 1967), oceanic islands are critically important for the particular biodiversity they harbor (Carlquist 1974; Porter 1976). Island ecosystems typically support unique biotic communities, with a higher proportion of endemic taxa than continents (Paulay 1994). Consequently, these species-poor island communities evolve under low pressure from competitors and natural enemies, rendering island ecosystems especially vulnerable to the introduction of exotic species (for a review, see Van Leeuwen et al. 2005). Therefore, it is not surprising that $80 \%$ of the recorded extinctions since ca. 1600 have occurred on islands (Groombridge 1992).

There is now an increasing recognition that species lists alone provide limited information to guide conservation efforts because they ignore complex networks of antagonistic and mutualistic interactions that maintain functional natural communities (Bond 1994; Bascompte et al. 2003). These interactions, although recognized by early ecologists (Darwin [1859] referred to them as nature's "entangled bank"), are still not given the attention they deserve in conservation planning (Memmott et al. 2007), particularly on oceanic islands (Kaiser-Bunbury et al. 2010). This is due, in large part, to a scarcity of information on frugivory and seed dispersal on oceanic islands,
Figure 1 Map of the Galápagos archipelago, showing its global location (inset) and the main islands.




as well as to the high investments in sampling effort and financial resources required.

Owing to their relative ecological simplicity, their spatial isolation, and the high degree of endemism, islands are frequently referred to as "natural laboratories" for the study of evolutionary and ecological processes. Despite the central role of the Galápagos for the origin and development of new concepts in ecology and evolution, our understanding of several important ecological processes, particularly that of seed dispersal, in the archipelago remains basic. Here, we begin filling this gap by assembling and synthesizing information from disparate sources into a review of the knowledge of endozoochorous seed dispersal systems in the Galápagos. Our objectives are 2fold: (i) to compile existing information on the interactions between plants and frugivorous animals in the Galápagos; and (ii) to highlight particular areas where research on frugivory and seed dispersal can prove particularly relevant in both theoretical and applied terms.

\section{The Galápagos archipelago}

The Galápagos archipelago straddles the equator $\left(1^{\circ} 40^{\prime} \mathrm{N}-1^{\circ} 36^{\prime} \mathrm{S}, 89^{\circ} 16^{\prime}-92^{\circ} 01^{\prime} \mathrm{W}\right)$ in the Eastern Pacific, approximately $960 \mathrm{~km}$ west of mainland Ecuador (Fig. 1). With an area of $7882 \mathrm{~km}^{2}$, the archipelago consists of 123 islands of volcanic origin, rising from a few meters to approximately $1700 \mathrm{~m}$ above sea level (Tye et al. 2002). Seven of the islands are larger than $100 \mathrm{~km}^{2}$ and 18 are greater than $1 \mathrm{~km}^{2}$ (Snell et al. 1996). The oldest lava flows on the eastern islands have been aged to no more than 4 million years, whereas the youngest islands, Fernandina and Isabela, to the west, are less than 0.5 million years old (White et al. 1993). The isolation and location of the archipelago with respect to oceanic currents and trade winds have favored a high degree of endemism: $59 \%$ of all vertebrates are endemic (Tye et al. 2002), with endemism especially high among terrestrial birds (84\%).

The flora of the Galápagos is closely related to that of South America, from where most plant propagules originated (Hooker 1847), probably transported to the archipelago by oceanic currents, wind, or birds (either as ingested seeds or attached to the body; Porter 1983). Differences in the dispersal efficiency of plant families resulted in a disharmonic flora, typical of oceanic islands (Baur 1891). The Galápagos flora consists of approximately 557 native (including 62 doubtfully native) vascular plant species, of which approximately 185 are endemic and 825 are exotic species (Galápagos flora database, Charles Darwin Research Station 2010; but see also Van Leeuwen et al. 2008).
The native vegetation is distributed in distinct zones that are largely related to local climatic conditions (Wiggins \& Porter 1971). These zones are classified as follows: (i) the littoral zone, including the mangroves; (ii) the arid zone, which dominates the archipelago, found on all but the smallest islets, and contains the highest plant endemism (including Opuntia and other Cactaceae) and has the greatest diversity of plant communities (Tye et al. 2002); (iii) the transition zone, located between the arid and humid zones, containing a mixture of plants from these 2 zones; and (iv) the humid zone, which forms the wettest and most biologically productive regions of the archipelago because of high precipitation (Wiggins \& Porter 1971; Tye et al. 2002). Only 7 islands are high enough to develop a humid zone (San Cristóbal, Santa Cruz, Floreana, Fernandina, Santiago, Isabela, and Pinta).

Plant invasions are concentrated, but not limited to, the 4 inhabited islands (Santa Cruz, San Cristobal, Isabela, and Floreana), particularly impacting humid habitats surrounding the agricultural and urban zones (Guerrero et al. 2007; Guézou et al. 2010).

Several invasive plant species, including the fleshyfruited Psidium guajava (guava) and Rubus niveus (blackberry), have severely altered the composition and structure of the natural ecosystems (Jaramillo 1999; Tye et al. 2007). The Galápagos National Park maintains a permanent control program for invasive species in areas of high ecological value on the 4 populated islands, investing approximately US $\$ 0.5$ million each year (Parque Nacional Galápagos 2009).

The seasonal climate of the Galápagos is atypical of other equatorial oceanic islands because of its location in the eastern Pacific, which means that it is influenced by several weather systems and oceanic currents (Colinvaux 1984). There are 2 distinct climatic seasons in the Galápagos. The hot season prevails from January to May and is characterized by warm sea and air temperatures $\left(24-29^{\circ} \mathrm{C}\right)$ with a highly variable rainfall (ranging between 64 and $2769 \mathrm{~mm}$ annually on the coast). The cool season occurs from June to December and is characterized by prolonged cloud cover and perpetual drizzle in the highlands, little or almost no rain throughout the dry lowlands, and temperatures ranging between 19 and $23^{\circ} \mathrm{C}$ (Trueman \& d'Ozouville 2010). The cyclic El Niño events cause prolonged intense rains, usually followed by a period of drought (Snell \& Rea 1999). Rainfall is lowest on the coast and increases with altitude, especially on the southern slopes of the highest islands (Tye et al. 2002).

Because of their relatively late discovery (1535), the 
harsh conditions faced by settlers, and the early establishment of the Galápagos Natural Park, the archipelago has remained relatively unspoiled (Gardener et al. 2010). Throughout the last century, the establishment of permanent human settlements and, in particular, the deliberate introduction of exotic plants and animals severely impacted large areas of the archipelago (Mauchamp 1997; Sulloway 2009; Guézou et al. 2010). Nevertheless, the Galápagos is today one of the best-preserved oceanic archipelagos, where human impacts on many ecological processes are still relatively low (Thornton 1971; Loope et al. 1988), particularly in the uninhabited islands. Therefore, and notwithstanding the permanent threat posed by invasive species, the Galápagos archipelago offers one of the last opportunities to study little-altered natural processes, including seed dispersal.

\section{MATERIALS AND METHODOLOGY}

A thorough literature search was performed using Internet scientific search engines (http://www.scholar. google.com and http://www.isiknowledge.com/WOS), as well as by searching the publications available in the library of the Charles Darwin Foundation (Puerto Ayora, Santa Cruz, Galápagos).

All interactions that described the consumption of fruits or seeds by animals were extracted and coded according to 4 categories as follows: (i) "frugivory" if fruit consumption is confirmed without clear information on seed fate; (ii) "seed predation" if there is evidence of the physical or chemical destruction of seeds; (iii) "potential seed dispersal" if entire seeds are identified in stomach contents or feces, but there is no confirmation of seed viability; and (iv) "seed dispersal" if viability of the dispersed seeds is observed. Broad or ambiguous taxonomic groups, such as finches, birds, or grasses, were not included in the analysis but, when relevant, are discussed in the literature review. Differences in the interaction frequency between animals and plants were explored applying likelihood ratio tests. For analysis, multiple interaction types (e.g. seed predation, seed dispersal) assigned to the same plant-animal pair were treated as independent observations.

\section{RESULTS}

\section{Chronological literature overview}

The first naturalists to explore the Galápagos Islands, including Charles Darwin, focused chiefly on the taxonomy and morphology of the fauna and flora, with little account of any interactions observed between the two. At the begin- ning of the $20^{\text {th }}$ century, particularly with the expedition of the California Academy of Sciences (1905-1906), explorers provided the first systematic records of frugivory in the archipelago (Stewart 1911; Gifford 1919), although most attention was still devoted to establishing the taxonomic borders of species and only a few feeding records were provided of the most conspicuous interactions, usually from giant tortoises (Chelonoidis nigra) and land iguanas (Conolophus spp.) (Beebe 1924).

Despite his short stay in the Galápagos, ornithologist David Lack's observations supported the idea that access to food, particularly fruit and seeds, could be the selective pressure driving the morphological differences among Galápagos finches (Lack 1947). Lack's work, and subsequent studies (e.g. Bowman 1961), brought considerable attention to frugivory and granivory among this group of birds, although none of the studies considered the potential role of seed dispersal. Although the potential role of Galápagos finches as seed dispersers did not strike Richard Bowman, giant tortoises did and, in 1961, Charles Rick and Bowman published the first study on animal seed dispersal in the Galápagos (Rick \& Bowman 1961). They explored the positive effect of seed ingestion by giant tortoises on the germination of Galápagos tomato (Solanum cheesmanii) seeds, which experienced extremely low germination rates in the absence of tortoise dispersal. Later, the same experimental approach was extended to birds and showed that Galápagos mockingbirds (Mimus parvulus) enhanced the germination of $S$. cheesmanii, whereas Galápagos finches (Geospiza magnirostris and Platyspiza crassirostris) acted mainly as seed predators (Rick 1964). Although thorough investigations, the work of Rick and Bowman was based on fruit fed to captive animals and seed dispersal in the wild remained unstudied, with only a passing reference to seeds of $S$. cheesmanii recovered from the feces of Rattus sp. that did not germinate (Rick 1964). More recent studies have shown that consumption by giant tortoises and land iguanas increases the germination rate of Opuntia echios (Estupiñán \& Mauchamp 1995) and that Galápagos mockingbirds generally pass the seeds of ingested fruits intact, whereas medium (Geospiza fortis) and small (G. fuliginosa) ground finches usually crush the seeds before ingesting them (Buddenhagen \& Jewell 2006).

The long-term studies by Peter and Rosemary Grant and their students, chiefly on Daphne Major but also in Genovesa and several other islands, are a milestone in our understanding of how selective pressures shape species evolution and of plant-animal interactions in the Galápagos. Their long-term datasets follow the evolution- 
ary ecology of ground finches from what was probably the worst drought of the century (1977) to the extraordinary El Niño of 1982-1983 (the year of the "great flood" [Grant \& Grant 1987; Weiner 1995]). On what is an extremely dry archipelago, rain is a limiting factor for vegetation productivity and, consequently, for frugivorous and granivorous animals (Boag \& Grant 1984). The Grants and their colleagues established that the 4 species of ground finches on Daphne Major are highly dependent on seeds. During years of average or above average rainfall, all species can find enough seeds to survive and reproduce and there is considerable overlap in their diets. However, in years of low rainfall, and consequently low fruit and seed availability, birds that cannot compete successfully will not survive. Under such conditions, each species specializes in a particular niche for which its beak shape confers some advantage: small ground finches specialize in eating small, soft seeds (e.g. Paspalum galapageia, Aristida repens), the medium ground finches diversify their diets to encompass most seeds available, large ground finches (G. magnirostris) specialize cracking large, hard seeds (e.g. Tribulus cistoides, Bursera graveolens) and cactus finches (G. scandens) specialize in Opuntia spp. seeds (Grant 1981; Schluter 1982a; Boag $\&$ Grant 1984). These studies also resulted in the first detailed descriptions of the diet of Galápagos birds. However, the authors focused on fruits and seeds as sources of energy for birds coping with difficult environments and did not quantify variables related to seed dispersal per se, such as the proportion of seeds that avoid finch predation and thus achieve dispersal (Grant \& Grant 1982; Schluter 1982b). An important exception is the only study on secondary seed dispersal in the Galápagos by Grant et al. (1975), who discussed the role of predatory birds (short-eared owls [Asio flammeus] and Galápagos hawks [Buteo galapagoensis]) as seed dispersers because these species prey upon finches and rats, which regularly feed on fruits. The authors concluded that, although rare, secondary seed dispersal by these species might be disproportionately important for the long-distance, interisland dispersal of plants.

Two studies (Racine \& Downhower 1974; Downhower $\&$ Racine 1976) took a different approach and framed plant-animal evolution from the plant's perspective. These studies revealed that the morphology of Opuntia spp. and Croton scouleri is likely shaped by selective forces exerted by frugivores. Although highly speculative, these 2 studies represent the only attempt to make a link between the selective forces exerted by birds (predators and dispersers) on plant morphology and phenology.
Among reptiles, and although well represented on the Galápagos, the 7 species of endemic lava lizards (Microlophus spp.) have received relatively little attention from ecologists. In one of the few ecological studies on these species, Schluter (1984) discovered that herbivory increases with body size and that the seeds of Lantana peduncularis passed intact through the lizards' digestive tract. Given the distribution and abundance of the genus, they are likely an underappreciated group in terms of their seed dispersal capacity. Carpenter (1969) provided another example of saurochory by describing seed dispersal of Opuntia spp. by land iguanas (Conolophus spp.). He also found several other species of seeds in droppings, but did not identify them. Although they are likely to be important dispersers, the only published accounts of frugivory in land iguanas are Opuntia spp., Psidium galapageium, and Scutia spicata (McMullen 1999).

The diet of the giant tortoises was studied by Cayot (1987), who compiled historical diet records and conducted her own studies with wild tortoises in Santa Cruz and Pinzón. She described over 60 taxa of plant foods, but only in 3 cases (Citrus sp., Hippomane mancinella, and $P$. galapagieum) was the consumption of fruits confirmed. However, in an ongoing study on Santa Cruz, Steve Blake and colleagues have so far found at least 46 species of intact seeds from dung piles (Blake et al., unpubl. obsv., 2010).

Studies of fruit consumption by mammals in the Galápagos are restricted to those of Deborah and David Clark on black rats (Rattus rattus) on Santa Cruz, Pinzón, and Santiago. Black rats include several fruits in their diet and, although they act primarily as seed predators, the dispersal of intact seeds was shown only for seeds of Miconia robinsoniana (Clark 1980; Clark 1981). In the same study, Clark and Clark (1981) observed that 10 years after the extermination of feral goats (Capra hircus) on the island of Santa Fé, the population of Bursera graveolens consisted of 2 distinct groups: (i) old, large adult trees; and (ii) juveniles recruiting away from the canopy of adult plants. The authors therefore speculated that animal seed dispersal must play an important role in the recruitment of this species. More recently, the use of the spool-and-line method suggested that the coexistence between the endemic Santiago rice rat (Nesoryzomys swarthi) and the invasive black rat could be maintained by differential fruit consumption (Gregory \& Macdonald 2009). However, although this method is useful to detect plant visitation trends, it cannot accurately inform whether fruits are consumed, or on the treatment conferred to the seeds.

In his classic book on Galápagos natural history, Ian 
Thornton (1971) first brought attention to the increasing threat that exotic vegetation poses to the native flora by suggesting that feral goats were dispersing the exotic guava $(P$. guajava). However, until recently, the role of animals as vectors of plant invasions was only supported by anecdotal references (e.g. cattle and birds; Schofield 1989; Lawesson $\&$ Ortiz 1994). Later, quantitative research evaluated the role of the introduced garrapatero (Crotophaga ani) as a potential seed disperser for both native and exotic plant species (Ballesteros 1984; Jara 1995; Soria 2006).

Most recently, 2 studies have attempted to quantify seed dispersal and measure dispersal effectiveness by conducting viability tests and germination trials of dispersed seeds. Soria (2006) assessed the role of 7 bird species on the dispersal of blackberry ( $R$. niveus), one of the most problematic invasive plants in the archipelago. Of the 7 bird species investigated, 5 dispersed viable seeds, with the introduced garrapatero (C. ani) being the most effective. Contrary to general opinion, Guerrero and Tye (2009) found that Galápagos finches are not simply seed predators, but that they can also be important seed dispersers. All 9 species studied ate fruits and 7 species defecated viable seeds. Interestingly, feces from 2 species generally assumed as insectivorous, namely the woodpecker finch (Camarhynchus pallidus) and warbler finch (Certhidia olivacea), contained high proportions of intact seeds.

\section{Frugivory and seed dispersal: a quantitative analysis}

Plant-animal frugivorous interactions were retrieved from 43 studies (Appendix 1) and compiled into an interaction matrix (Table 1). Table 1 describes 366 unique interactions between 26 animal species and fruits or seeds of 136 plants species. Most of these interactions (174; $48 \%$ ) refer to the consumption of fruits or seeds with no indication on seed fate (i.e. frugivory). Seed predation was confirmed in 150 (41\%) of the interactions and seed dispersal was assumed in $83(23 \%)$ cases, but seed viability was only confirmed on 6 occasions (1.6\%).

Although the majority (72\%) of interactions involve seeds of native species, more than one-quarter (28\%) involve introduced species. Seed dispersal has more often been confirmed for Solanaceae and Cactaceae, due, in part, to the disproportionate influence of Solanum lycopersicum and Opuntia echios, respectively. Poaceae species dominate the records of frugivory and seed predation. Regarding animals, interactions involving birds are considerably more numerous than those involving reptiles and mammals, in terms of both seed dispersal $(63 \%, 10 \%$, and $27 \%$, respectively) and seed predation $(68 \%, 0 \%$, and $32 \%$, respectively). There were no significant differences between the proportion of introduced fruits consumed by birds (28\%), mammals (30\%), and reptiles $(22 \% ; G=0.47 ; d f=2 ; P=0.791)$. Seed dispersal was more often confirmed or suggested (i.e. potential seed dispersal) for introduced plants ( $28 \%$ of the interactions) than for native plants $(17 \% ; G=6.63 ; d f=2 ; P=0.036)$. Similarly, seed dispersal (confirmed and potential) was proportionally more common among reptiles $(50 \%$ of the interactions) than among birds (16\%) or mammals (32\%; $G$ $=62.6 ; d f=2 ; P<0.001$ ).

\section{DISCUSSION}

Advances in our understanding of frugivory and seed dispersal in the Galápagos can be summarized in 3 general phases defined by 3 distinct time frames. For most of the $20^{\text {th }}$ century, the debate has been dominated by the influence of seed consumption as a driving force for the morphological adaptations of animal species. This debate provided vast information on the consumption of fruits mostly by Galápagos finches; however, it has neglected the role of animals as seed dispersers. In the second phase, several studies focused on seed dispersal from at least 3 perspectives: (i) the treatment conferred to seeds by captive animals; (ii) the role of animal seed dispersal in assisting plant invasions; and (iii) the potential importance of secondary seed dispersal. Finally, 2 recent studies (Soria 2006; Guerrero \& Tye 2009) applied stronger scientific protocols to assess seed dispersal effectiveness for focal groups of plants (R. niveus) and birds (Galápagos finches).

The data suggest that, despite the historical importance of understanding the diet of Galápagos finches, the critical ecosystem function of seed dispersal remains largely unknown for the archipelago. Given the relatively low animal diversity, plants on oceanic islands are generally served by a reduced number of seed dispersers (KaiserBunbury et al. 2010). Therefore, shifts in the assemblage of frugivores can more easily influence future vegetation, and hence ecosystem structure, by altering seed deposition patterns. Clear examples of such disruptions have been documented in other oceanic archipelagos, such as Hawaii (Chimera \& Drake 2010) and the Canary Islands (Nogales et al. 2005; López-Darias \& Nogales 2008).

That introduced plants participate in $28 \%$ of the interactions compiled in the present study is a worrying statistic considering the uniqueness of the Galápagos endemic flora and particularly considering that introduced plants were more often involved in seed dispersal interactions (compared with frugivory and seed predation) than native plants. 
Table 1 Interaction matrix between frugivores and seeding plants in the Galápagos based on published literature






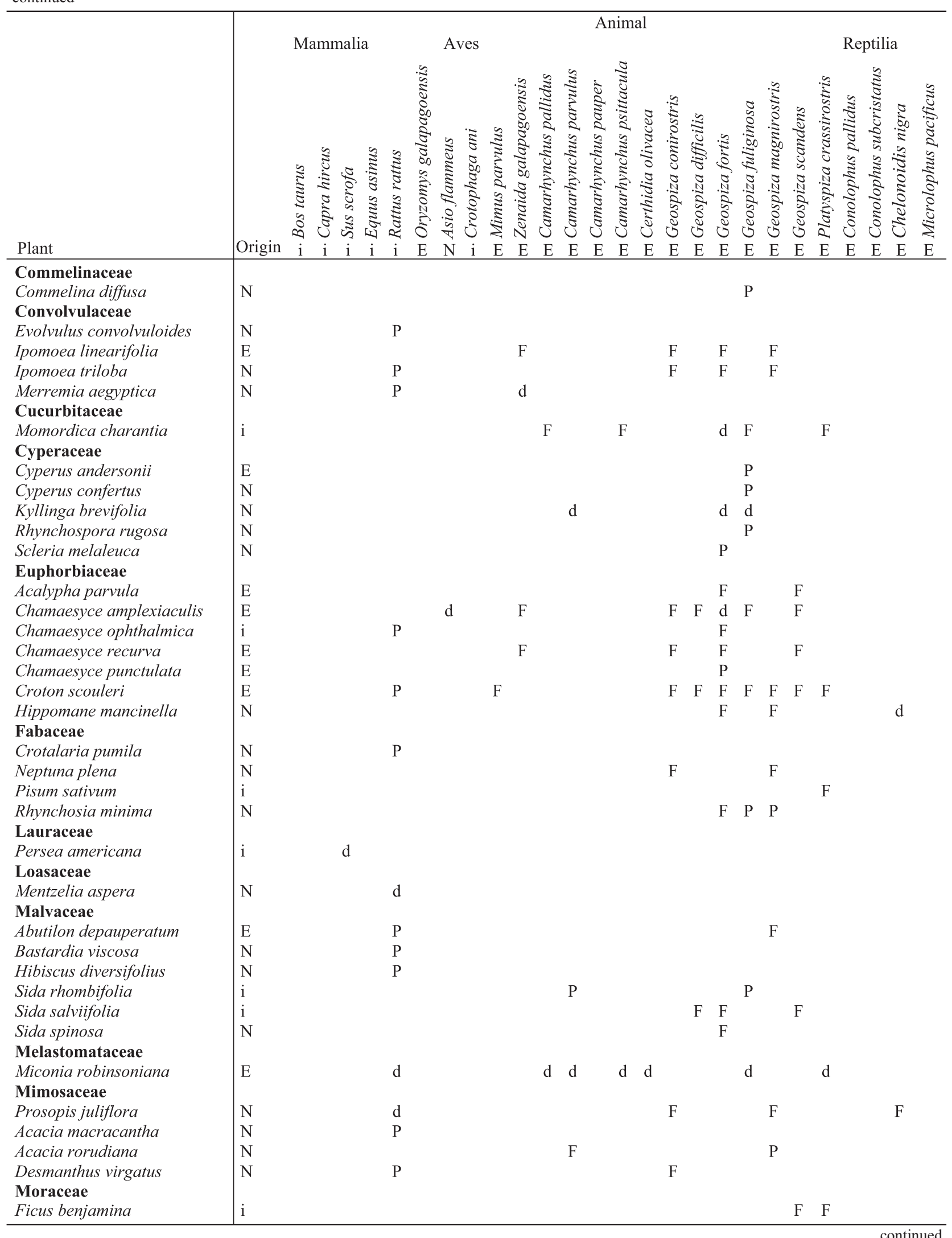




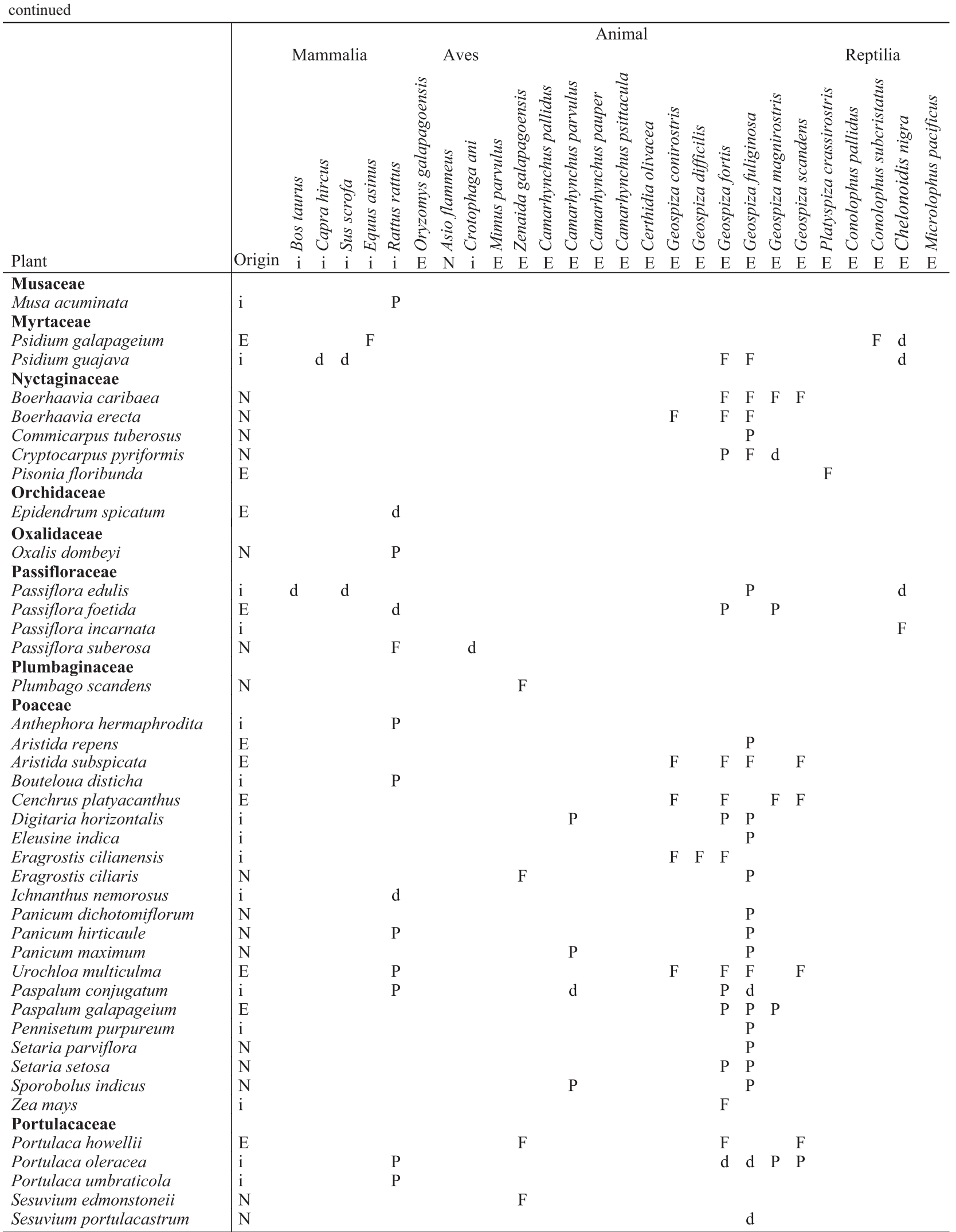

continued 


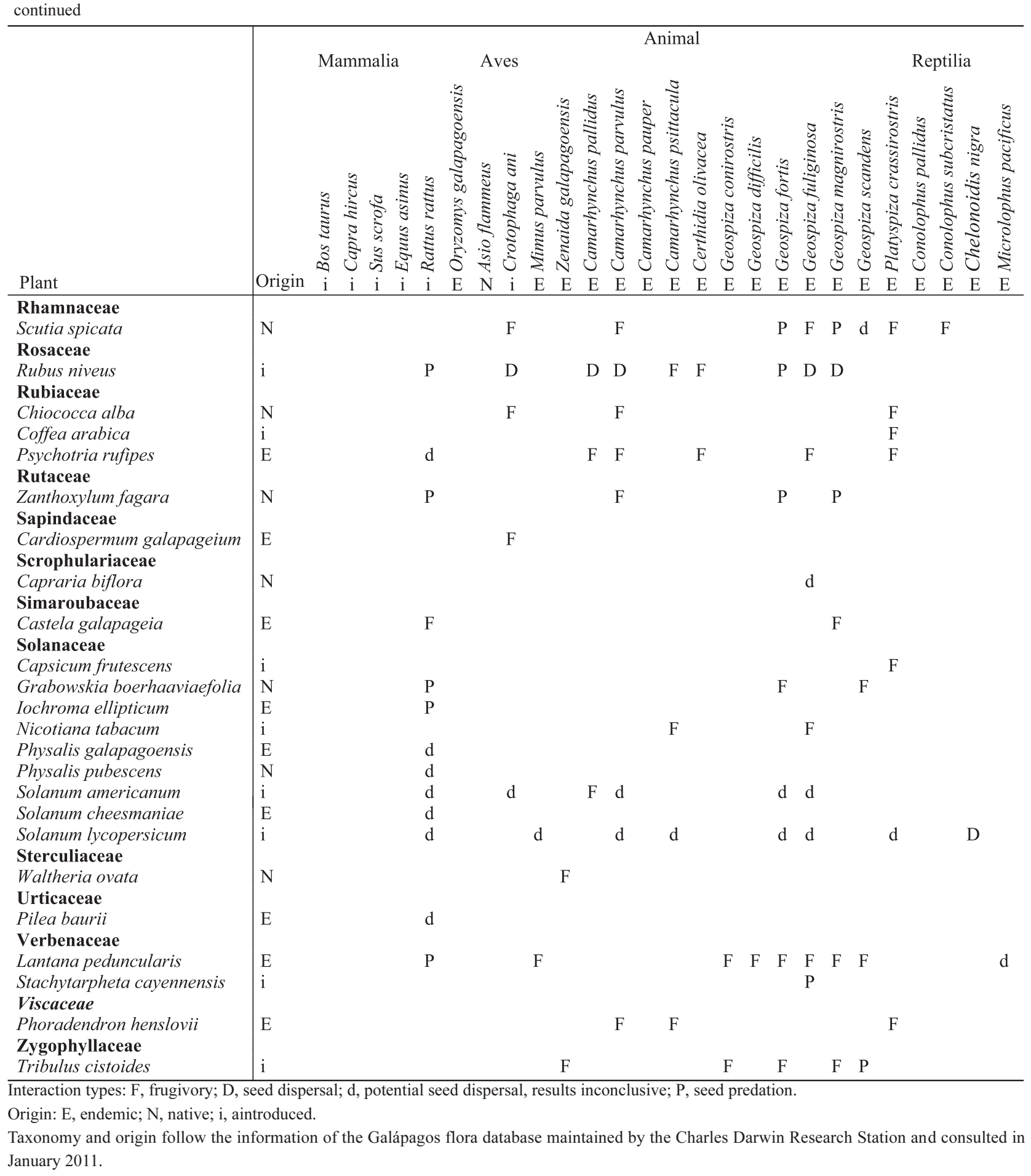

Interestingly, and despite the large information deficit, 9 of the 18 interactions between plants and reptiles are of seed dispersal and there are no records of seed predation among this group. The apparent high effectiveness of rep- tiles as seed dispersers contrasts with the lower effectiveness (sensu lato) of birds (56 dispersal interactions of 349 interactions in total). However, given the different research interests that have dominated reptile and bird studies in 
the archipelago (with most avian studies focusing on seed predation), further unbiased studies are needed to clarify this pattern in the Galápagos, as shown for other tropical and subtropical archipelagos (Nogales et al. 2005).

Given the absence of specialized frugivores in the Galápagos, the potential importance of seed dispersal and its impacts has been underappreciated (Soria et al. 2002). However, recent studies in the Galápagos and elsewhere call for a re-evaluation of the role of animals typically disregarded as seed dispersers (Soria 2006; Guerrero \& Tye 2009; Heleno et al. 2011).

\section{Future avenues of research}

Based on the present literature review, we highlight 3 promising avenues for future research and important steps to translate research output into action, as outlined below.

\section{Systematic, un-biased and targeted baseline research}

Data on frugivory and seed dispersal have not been collected either randomly or systematically, neither in space, time, nor through taxonomic groups. For logistic reasons, most studies have focused on inhabited or easily accessible islands (with some important exceptions) and, within these, on most accessible habitats (particularly the dry zone). Future studies should address these weaknesses by conducting multiyear studies and collecting data from poorly studied islands (e.g. Fernandina) and habitats (e.g. humid zone). Similarly, most studies have been conducted during nonrandom time frames, generally during the wet/hot season and only rarely including El Niño years, which hampers the ability to detect temporal trends. Most worrisome is that in some studies that encompass several islands, it is often not clear where each interaction was detected, something that should be corrected in future studies. Finally, studies have been biased towards birds, with much less information from other taxonomic groups (e.g. mammals and reptiles) and, within birds, considerably more effort has been devoted to identifying trophic rather than mutualistic interactions. A community-level approach to the implications of frugivory and seed dispersal for ecosystem functioning should be developed, particularly focusing on the challenge of maintaining functional habitats threatened by invasive plants.

Despite the status of "natural laboratory" often conferred to the Galápagos Islands (Jäger et al. 2007; but see also Deem et al. 2010), there has been no rigorous study on interisland seed dispersal. Secondary seed dispersal by raptors has been suggested to be disproportionally important to interisland seed dispersal (Grant et al. 1975). Molecular analysis suggests negligible interisland gene flow in the Galápagos hawk (Bollmer et al. 2005), sug- gesting that it may not be important for seed dispersal between distant islands. Conversely, the recent discovery of several rodent skulls in short-eared owl (A. flammeus) pellets in Champion, a rodent-free islet by the coast of Floreana (Heleno, unpubl. data, 2010), strengthens the case for frequent interisland movements of these birds and their potential role as secondary seed dispersers, at least between nearby islands. As in other oceanic islands (Nogales et al. 2007), the importance of this mechanism remains largely underevaluated in the Galápagos. Given the good knowledge of each island's flora and fauna, the archipelago offers a privileged situation for testing hypotheses related to interisland seed dispersal, such as the relative effectiveness of dispersal syndromes.

Finally, long-term information on the productivity of fruit-bearing plants would be extremely valuable when identifying patterns regarding the diet preferences of frugivorous animals. Grant and Grant (1990) pointed out that "This gap in our knowledge has pinpointed a general deficiency; there are no seed- and fruit-production values for any plant species in the Galápagos archipelago". Even if progress has been made, there is still the need for consistent long-term patterns of fruit production.

\section{A network approach}

Ecological networks have provided useful tools for understanding and managing environmental threats, such as biological invasions, global change, habitat fragmentation, and the pollination crisis (Kremen \& Hall 2005; Tylianakis et al. 2008; Heleno et al. 2009). Due to the simplified communities of oceanic islands, such an approach can be particularly insightful, although seed dispersal networks on islands are extremely rare (Kaiser-Bunbury et al. 2010). Ongoing research is taking this network approach for the first time in the Galápagos and is providing information on new interactions, on how the community of seed dispersers is structured, and on how alien invasive species may affect the topology of such networks.

High-quality, quantitative ecological networks, such as food webs or seed dispersal networks, can prove important in 3 stages of ecological conservation: (i) as a tool to detect and quantify direct and indirect impacts of a particular threat; (ii) as a roadmap to aid in the preparation of effective management plans aiming to manage communities as a whole; and (iii) as a benchmark to measure the success of restoration programs.

To implement such a holistic approach implies a large and systematic sampling effort to make sure all interactions (e.g. birds, mammals, and reptiles) are given the same detection probability; however, data obtained in this way 
could be used to detect and predict often elusive impacts in species interactions patterns (Simberloff 2004; Kremen \& Hall 2005).

\section{Frugivory as a selective pressure}

Dispersal is critically important for the biogeography and evolution of biodiversity on oceanic islands (Cowie \& Holland 2006). The Galápagos archipelago has provided key information on how plants affect frugivores by changing food supply, but little is known about how frugivores affect plant population dynamics and evolution. Like frugivorous animals, plants too have to face reciprocal selective pressures by attracting legitimate seed dispersers while avoiding physical and chemical destruction from seed predators. Thus, natural selection is likely to benefit the recruitment of seeds not preferred by predatory finches. As described by Racine and Downhower (1974), the different assemblages of seed predators and seed dispersers in each island (Table 1) make the Galápagos an excellent location in which to test hypotheses in this field. For example, it has been suggested that the now extinct race of Geospiza magnirostris var. magnirostris of Floreana had an abnormally large beak that allowed it to exploit the similarly abnormal seeds of the endemic variety of Opuntia megasperma var. megasperma (Steadman \& Zousmer 1988). In fact, the range loss of this plant, largely consumed by domestic animals, may explain the local extinction of this bird. Although highly plausible, both hypotheses are impossible to test a posteriori, highlighting the need for timely data.

The relative ecological simplicity and presence of a megaherbivore (the giant tortoise) in the Galápagos provides an excellent opportunity to study the impact of a potential ecosystem engineer on plant dynamics and community structure, with highly relevant practical applications. Galápagos tortoises can attain high biomass and are generalist herbivores with rather simple digestive processes; thus, much of their food passes through the gut relatively intact. Tortoises, especially giant tortoises, are keystone species in some environments (Hansen et al. 2010) and, with a body size an order of magnitude larger than any other terrestrial vertebrate, are likely to be so on the Galápagos. Galápagos tortoises are extinct on several islands, although there are plans for repatriation to restore these ecosystem processes (Tapia 2009). A critical component of these restoration programs will be to dedicate research to understanding the role of the tortoise in the Galápagos ecosystem functioning.

The dispersal of highly different seeds by a multitude of vectors, across habitats, and for highly variable distances is inherently hard to follow. Traditional methods of direct observations of movement patterns based on ra- diotelemetry or mark-recapture methods do not render appropriate data to assess the extent of seed dispersal and plant colonization. Nevertheless, solutions are now available, such as stable isotopes analysis (Wang \& Smith 2002; Carlo et al. 2009), radioactive labeling (Vander Wall 1994), and molecular genetic markers (Cain et al. 2000; Jordano et al. 2007).

In particular, the introduction of molecular techniques has made it possible to estimate gene flow and population genetic structure, and thus the colonization and evolutionary history, of populations. For example, the distribution of molecular lineages (phylogeography) of Bursera spp. is congruent with high interisland genetic exchange via seed dispersal by birds (Weeks \& Tye 2009), a pattern shared by Opuntia spp. (Helsen et al. 2009).

\section{Translating research outputs into management action}

To become practically relevant, the results of the research described above needs to be communicated properly to the Galápagos National Park and other stakeholders. Information regarding seed dispersal may prove important in the conservation of threatened species and ecological restoration (Ingle 2003). The incorporation of a fleshy-fruited exotic plant into the diet of native frugivores, particularly birds (Timmins \& Williams 1987), is frequently an important step in that species becoming invasive (Bartuszevige \& Gorchov 2006; Buckley et al. 2006). Therefore, information on seed dispersal is most important when dealing with fleshy-fruited plant invasions (Williams \& Karl 1996), possibly the threat with most potential impact in the Galápagos biota. Given the severe impact of invasive plants in the Galápagos and the amount of research dedicated by the Charles Darwin Foundation and the Galápagos National Park to the problem of invasive species, it is surprising that there is not a robust unified assessment of seed dispersal vectors in the archipelago.

Given the increasing prevalence of alien species worldwide (D'Antonio \& Chambers 2006), restoration ecologists are frequently faced with the challenge of managing invaded ecosystems (Vander Zanden et al. 2006; Forup et al. 2008). As an ecosystem function with direct consequences for the biologic community, seed dispersal has often been suggested as an integrated yardstick with which to measure the effectiveness of ecological restoration (Olesen \& Valido 2003; Heleno et al. 2010; KaiserBunbury et al. 2010).

Another use of seed dispersal information is to identify the consequences for plants of the local extinction of 
frugivores (Kaiser-Bunbury et al. 2010). In the Galápagos, there have been few local extinctions since human arrival (e.g. giant Tortoises on Pinta [now reintroduced], Santa Fé, and Floreana; the Floreana Mockingbird [Mimus trifasciatus] and the large-ground-finch [G. magnirostris] from Floreana; 3 endemic species of rice rat [Oryzomys spp.] from San Cristóbal; and possibly the vermilion flycatcher [Pyrocephalus rubinus] also from San Cristóbal). Without baseline information on the interactions that these species established in the communities they were integrated in and on the ecosystem functions they performed, it is now impossible to rigorously assess the communitywide effect of their absence.

Three applied problems where seed dispersal information is only recently being implemented for the first time, but where advances are most expected, are in improving eradication protocols for invasive plants, planning conservation strategies based on the manipulation of seed dispersal, and preventing further introductions. Finally, there is now a solid body of evidence suggesting that climate change will affect fruit production, seed dispersal, and the spread of exotic vegetation throughout the world (Dukes \& Mooney 1999; Mainka \& Howard 2010). Again, islands are at greater risk than continents (Kaiser-Bunbury et al. 2010); thus, accurate predictions and strategies to mitigate different kinds of impacts are critically needed (Mainka \& Howard 2010).

The need of direct cooperation between scientists and conservation managers has been more often preached than put into practice. However, when cooperation has been possible, it has generally resulted in positive results for scientists, managers, and the ecosystems in which they work. The Galápagos is no exception and plant-frugivore interactions represent a highly desirable bridge.

The importance of seed dispersal for the Galápagos is reflected by the current research interest devoted to filling some of the information gaps highlighted in the present article. These studies include an assessment of the ecological role of giant tortoises as megaherbivores, the effectiveness of non-finch birds as seed dispersers, and the study of seed dispersal networks at the community level. We therefore expect that the coming years will substantially consolidate our understanding of the seed dispersal systems in this unique archipelago.

\section{ACKNOWLEDGMENTS}

The present study was part of a biodiversity project funded by the BBVA Foundation (Spain). The authors thank Ana Guerrero for her help with early versions of the manuscript and to Susana Chamorro for introducing us to "Las Encantadas". The authors are also grateful to the Galápagos National Park and to the Charles Darwin Foundation, particularly Sally Taylor for her help in the library and to Mark Gardener for his comments on the manuscript.

\section{REFERENCES}

Ballesteros N (1984). Los garrapateros en la parte alta de la Isla de Santa Cruz. Colegio Nacional Galápagos (BSc thesis). Curso Químico Biólogo, Santa Cruz, Ecuador.

Bartuszevige AM, Gorchov DL (2006). Avian seed dispersal of an invasive shrub. Biological Invasions 8, 1013-22.

Bascompte J, Jordano P, Melian CJ, Olesen JM (2003). The nested assembly of plant-animal mutualistic networks. Proceedings of the National Academy of Sciences of the United States of America 100, 9383-7.

Baur G (1891). The origin of the Galapagos Islands. The American Naturalist 25, 217-29.

Beebe W (1924). Galapagos: World's End. Putnam's Sons, London.

Boag GT, Grant PR (1984). Darwin's finches (Geospiza) on isla Daphne Major, Galápagos: breeding and feeding ecology in a climatically variable environment. Ecological Monographs 54, 463-89.

Bollmer JL, Whiteman NK, Cannon MD, Bednarz JC, De Vries T, Parker PG (2005). Population genetics of the Galapagos hawk (Buteo galapagoensis): genetic monomorphism within isolated populations. Auk 122, 121024.

Bond WJ (1994). Do mutualisms matter: assessing the impact of pollinator and disperser disruption on plant extinction. Philosophical Transactions of the Royal Society of London Series B Biological Sciences 344, 8390.

Bowman RI (1961). Morphological differentiation and adaptation in the Galapagos finches. University of California Publications in Zoology 58, 1-302.

Buckley YM, Anderson S, Catterall CP et al. (2006). Management of plant invasions mediated by frugivore interactions. Journal of Applied Ecology 43, 848-57.

Buddenhagen C, Jewell KJ (2006). Invasive plant seed viability after processing by some endemic Galapagos birds. Ornitología Neotropical 17, 73-80.

Cain ML, Milligan BG, Strand AE (2000). Long-distance seed dispersal in plant populations. American Journal of Botany 87, 1217-27.

Carlo TA, Tewksbury JJ, del Rio CM (2009). A new method 
to track seed dispersal and recruitment using N-15 isotope enrichment. Ecology 90, 3516-25.

Carlquist S (1974). Island Biology. Columbia University Press, Columbia.

Carpenter C (1969). Behavioral and ecological notes on the Galápagos land iguana. Herpetologica 25, 155-64.

Cayot L (1987). Ecology of giant tortoises (Geochelone elephantopus) in the Galápagos Islands ( $\mathrm{PhD}$ thesis). The Graduate School of Syracuse University, New York, USA.

Clark DA (1980). Age- and sex-dependent foraging strategies of a small mammalian omnivore. Journal of Animal Ecology 49, 549-63.

Clark DA (1981). Foraging patterns of black rats across a desert-montane forest gradient in the Galapagos Islands. Biotropica 13, 182-94.

Clark DA, Clark DB (1981). Effects of seed dispersal by animals on the regeneration of Bursera graveolens (Burseraceae) on Santa Fe Island, Galápagos. Oecologia 49, 73-5.

Colinvaux PA (1984). The Galápagos climate: present and past. In: Perry R, ed. Key Environments: Galápagos. Pergamon Press, Oxford, pp. 55-69.

Cowie RH, Holland BS (2006). Dispersal is fundamental to biogeography and the evolution of biodiversity on oceanic islands. Journal of Biogeography 33, 193-8.

Chimera CG, Drake DR (2010). Patterns of seed dispersal and dispersal failure in a Hawaiian dry forest having only introduced birds. Biotropica 42, 493-502.

D'Antonio CM, Chambers JC (2006). Using ecological theory to manage or restore ecosystems affected by invasive plant species. In: Falk DA, Palmer MA, Zedler L, eds. Foundations of Restoration Ecology. Island Press, Covelo, CA, pp. 260-79.

Darwin C (1859). On the Origin of Species by Means of Natural Selection, or the Preservation of Favoured Races in the Struggle for Life. John Murrey, London.

Deem SL, Blake S, Miller RE, Parker PG (2010). Unnatural selection in Galapagos: the role of disease in Darwin's Finches (Geospizinae). Galapagos Research 67, 62-4.

Dennis AJ, Schupp EW, Green AJ, Westcott DA eds. (2007). Seed Dispersal: Theory and its Application in a Changing World. CAB International, Wallingford.

Downhower JF, Racine CH (1976). Darwin's Finches and Croton scouleri: an analysis of the consequences of seed predation. Biotropica 8, 66-70.

Dukes JS, Mooney HA (1999). Does global change increase the success of biological invaders? Trends in Ecology \& Evolution 14, 135-9.
Estupiñán S, Mauchamp A (1995). Interacción planta-animal en la dispersión de Opuntia de Galápagos (unpublished Report). Charles Darwin Foundation, Puerto Ayora.

Forup ML, Henson KSE, Craze PG, Memmott J (2008). The restoration of ecological interactions: plant-pollinator networks on ancient and restored heathlands. Journal of Applied Ecology 45, 742-52.

Gardener MR, Atkinson R, Renteria JL (2010). Eradications and people: lessons from the plant eradication program in Galapagos. Restoration Ecology 18, 20-9.

Gifford EW (1919). Expedition of the California Academy of Sciences to the Galapagos Islands, 1905-1906. XIII: field notes on the land birds of the Galapagos Islands and of Cocos Islands, Costa Rica. Proceedings of the California Academy of Sciences 2, 189-258.

Grant BR, Grant PR (1982). Niche shifts and competition in Darwin's finches Geospiza conirostris and congeners. Evolution 36, 637-57.

Grant PR (1981). The feeding of Darwin's finches on Tribulus cistoides (L.) seeds. Animal Behaviour 29, 785 93.

Grant PR, Grant BR (1987). The extraordinary El Niño event of 1982-83: effects on Darwin's Finches on Isla Genovesa, Galapagos. Oikos 49, 55-66.

Grant PR, Grant BR (1990). Plant-animal interactions: consumption of seeds by Darwin's finches. Monograph in Systematic and Botany from the Missouri Botanical Garden 32, 179-87.

Grant PR, Smith JNM, Grant BR, Abbott IJ, Abbott LK (1975). Finch Numbers, owl predation and plant dispersal on Isla-Daphne-Major, Galapagos. Oecologia 19, 23957.

Gregory SD, Macdonald DW (2009). Prickly coexistence or blunt competition? Opuntia refugia in an invaded rodent community. Oecologia 159, 225-36.

Groombridge B (1992). Global Biodiversity: Status of the Earth's Living Resources. World Conservation Monitoring Centre. Chapman \& Hall, London.

Guerrero AM, Pozo P, Chamorro S, Guezou A, Buddenhagen $C E$ (2007). Baseline data for identifying potencially invasive plants in Puerto Ayora, Santa Cruz Island, Galápagos. Pacific Conservation Biology 14, 93-107.

Guerrero AM, Tye A(2009). Darwin's finches as seed predators and dispersers. The Wilson Journal of Ornithology $121,752-64$.

Guézou A, Trueman M, Buddenhagen CE et al. (2010). An extensive alien plant inventory from the inhabited areas of Galapagos. PLoS ONE 5, e10276. 
Hansen DM, Donlan CJ, Griffiths CJ, Campbell KJ (2010). Ecological history and latent conservation potential: large and giant tortoises as a model for taxon substitutions. Ecography 33, 272-84.

Heleno RH, Ceia RS, Ramos JA, Memmott J (2009). The effect of alien plants on insect abundance and biomass: a food web approach. Conservation Biology 23, 410-19.

Heleno RH, Lacerda I, Ramos JA, Memmott J (2010). Evaluation of restoration effectiveness: community response to the removal of alien plants. Ecological Applications 20, 1191-203.

Heleno RH, Ross G, Everard A, Ramos JA, Memmott J (2011). On the role of avian seed predators as seed dispersers. Ibis 153, 199-203.

Helsen P, Browne RA, Anderson DJ, Verdyck P, Van Dongen S (2009). Galápagos' Opuntia (prickly pear) cacti: extensive morphological diversity, low genetic variability. Biological Journal of the Linnean Society 96, 451-61.

Hooker J (1847). An enumeration of the plants of the Galapagos archipelago with descriptions of those which are new. Transactions of the Linnean Society of London 20, 163-233.

Howe HF, Smallwood J (1982). Ecology of seed dispersal. Annual Review of Ecology and Systematics 13, 201-28.

Ingle NR (2003). Seed dispersal by wind, birds, and bats between Philippine montane rainforest and successional vegetation. Oecologia 134, 251-61.

Jäger H, Tye A, Kowarik I (2007). Tree invasion in naturally treeless environments: Impacts of quinine (Cinchona pubescens) trees on native vegetation in Galápagos. Biological Conservation 140, 297-307.

Janzen DH (1971). Seed predation by animals. Annual Review of Ecology and Systematics 2, 465-92.

Jara M (1995). Aspectos ecológicos, distribución y abundancia del garrapatero Crotophaga ani en el sur de la isla Isabela, Galápagos-Ecuador (BSc thesis). Departamento de Biología, Pontificia Universidad Católica del Ecuador, Quito.

Jaramillo P (1999). Impact of human activities on the native plant life in Galapagos National Park. In: Ospina P, Muñoz E, eds. Galapagos Report. Fundación Natura and World Wildlife Fund, Quito, pp. 50-5.

Jordano P, García C, Godoy JA, García-Castano JL (2007). Differential contribution of frugivores to complex seed dispersal patterns. Proceedings of the National Academy of Sciences of the United States of America 104, 327882.

Kaiser-Bunbury CN, Traveset A, Hansen DM (2010). Con- servation and restoration of plant-animal mutualisms on oceanic islands. Perspectives in Plant Ecology, Evolution and Systematics 12, 131-43.

Kremen C, Hall G (2005). Managing ecosystem services: what do we need to know about their ecology? Ecology Letters 8, 468-79.

Lack D (1947). Darwin's Finches. Cambridge University Press, Cambridge, UK.

Lawesson JE, Ortiz L (1994). Plantas Introducidas en las Islas Galapagos. In: Carrasco A, Valdebenito H, eds. Investigación botánica y manejo en Galápagos. Fundación Charles Darwin, Quito, pp. 224-35.

Levey DJ, Silva WR, Galetti M (2002). Seed Dispersal and Frugivory: Ecology, Evolution and Conservation. CAB International, Wallingford.

Loope LL, Hamann O, Stone CP (1988). Comparative conservation biology of oceanic archipelagoes: Hawaii and the Galápagos. BioScience 38, 272-82.

López-Darias M, Nogales M (2008). Effects of the invasive Barbary ground squirrel (Atlantoxerus getulus) on seed dispersal systems of insular xeric environments. Journal of Arid Environments 72, 926-39.

MacArthur R, Wilson E (1967). The Theory of Island Biogeography. Princeton University Press, Princeton, US.

Mainka SA, Howard GW (2010). Climate change and invasive species: double jeopardy. Integrative Zoology 5, 10211.

Mauchamp A (1997). Threats from alien plant species in the Galápagos Islands. Conservation Biology 11, 260-3.

McMullen CK (1999). Flowering Plants of the Galapagos. Comstock Publishing Associates, Cornell.

Memmott J, Gibson R, Carvalheiro L et al. (2007). The conservation of ecological interactions. In: Stewart AA, New TR, Lewis OT, eds. Insect Conservation Biology. The Royal Entomological Society, London, pp. 226-44.

Nathan R, Muller-Landau HC (2000). Spacial patterns of seed dispersal, their determinants and consequences for recruitment. Trends in Ecology \& Evolution 15, 278-85.

Nogales M, Nieves C, Illera JC, Padilla DP, Traveset A (2005). Effect of native and alien vertebrate frugivores on seed viability and germination patterns of Rubia fruticosa (Rubiaceae) in the eastern Canary Islands. Functional Ecology 19, 429-36.

Nogales M, Padilla D, Nieves C, Illera J, Traveset A (2007). Secondary seed dispersal systems, frugivorous lizards and predatory birds in insular volcanic badlands. Journal of Ecology 95, 1394-403.

Olesen JM, Valido A (2003). Lizards as pollinators and seed 
dispersers: an island phenomenon. Trends in Ecology \& Evolution 18, 177-81.

Parque Nacional Galápagos (2009). Informe annual 2009. Puerto Ayora, Ecuador. (Unpublished.)

Paulay G (1994). Biodiversity on oceanic islands: its origin and extinction. American Zoologist 34, 134-44.

Porter DM (1976). Geography and dispersal of Galapagos islands vascular plants. Nature 264, 745-6.

Porter DM (1983). Vascular plants of the Galapagos: origins and dispersal. In: Bowman RI, Berson M, Leviton AE, eds. Patterns of Evolution in Galapagos Organisms. Pacific Division of AAAS, San Francisco, pp. 33-96.

Racine CH, Downhower JF (1974). Vegetative and reproductive strategies of Opuntia (Cactaceae) in the Galapagos Islands. Biotropica 6, 175-86.

Rick CM (1964). Some plant-animal relations on the Galapagos Islands. In: Bowman R, ed. Galápagos International Scientific Project. University of California Press, Berkeley, pp. 215-24.

Rick CM, Bowman RI (1961). Galapagos tomatoes and tortoises. Evolution 15, 407-27.

Ridley HN (1930). The Dispersal of Plants Troughout the World. L. Reeve \& Co., Kent.

Schluter D (1982a). Seed and patch selection by Galapagos ground finches: relation to foraging efficiency and foodsupply. Ecology 63, 1106-20.

Schluter D (1982b). Distributions of Galápagos ground finches along an altitudinal gradient: the importance of food supply. Ecology 63, 1504-17.

Schluter D (1984). Body size, prey size and herbivory in the Galapagos lava lizard, Tropidurus. Oikos 43, 291-300.

Schofield EK (1989). Effects of introduced plants and animals on island vegetation: examples from the Galapagos archipelago. Conservation Biology 3, 227-38.

Simberloff D (2004). Community ecology: is it time to move on? American Naturalist 163, 787-99.

Snell H, Rea S (1999). The 1997-1998 El Niño in Galápagos: can 34 years of data estimate 120 years of pattern? Noticias de Galápagos 60, 11-20.

Snell HM, Stone PA, Snell HL (1996). A summary of geographical characteristics of the Galápagos Islands. Journal of Biogeography 23, 619-24.

Soria M, Gardener MR, Tye A (2002). Eradication of potentially invasive plants with limited distributions in the Galápagos Islands. In: Veitch CR, Clout MN, eds. Turning the Tide: the Eradication of Invasive Species. IUCN SSC Invasive Species Specialist Group, IUCN, Gland and Cambridge, pp. 287-92.
Soria MC (2006). Avian Seed Dispersers of the Invasive Rubus niveus (Rosaceae) in Santa Cruz Island, Galapagos, Ecuador (Msc thesis). University of Missouri-St. Louis, St. Louis.

Steadman D, Zousmer S (1988). Galápagos. Smithsonian Institution Press, Washhington, D.C.

Stewart A (1911). Expedition of the California Academy of Sciences to the Galapagos Islands, 1905-1906. II: A botanical survey of the Galapagos Islands. Proceedings of the California Academy of Sciences 1, 7-288.

Stiles EW (2000). Animals as seed dispersers. In: Fenner M, ed. Seeds: the Ecology of Regeneration in Plant Communities. CAB International, Wallingford, pp. 11124.

Sulloway FJ (2009). Tantalizing tortoises and the DarwinGalapagos Legend. Journal of the History of Biology 42, 3-31.

Tapia W (2009). Plan para la restauración ecológica de la isla Pinta. Parque Nacional Galápagos, Puerto Ayora.

Thornton I (1971). Darwin's Islands: a Natural History of the Galapagos. Natural History Press, New York.

Timmins SM, Williams PA (1987). Characteristics of problem weeds in New Zealand's protected natural areas. In: Saunders DA, Arnold GW, Burbidge AA, Hopkins AJM, eds. Nature Conservation: the Role of Remnants of $\mathrm{Na}$ tive Vegetation. Surrey Beatty, CSIRO, CALM, Chipping-Norton, pp. 241-7.

Traveset A, Robertson AW, Rodríguez J (2007). A review on the role of endozoochory on seed germination. In: Dennis AJ, Schupp EW, Green AJ, Westcott DA, eds. Seed Dispersal: Theory and its Application in a Changing World. CAB International, Wallingford, pp. 78-103.

Trueman M, d'Ozouville N (2010). Characterizing the Galapagos terrestrial climate in the face of global climate change. Galapagos Research 67, 26-37.

Tye A, Atkinson R, Carrión V (2007). Incrementa el número de plantas introducidas en Galápagos. Informe Galápagos 2006-2007. Fundacíon Charles Darwin, Parque Nacional Galápagos, Instituto Nacional Galápagos, Puerto Ayora, pp. 137-9.

Tye A, Snell HL, Peck SB, Andersen H (2002). Outstanding terrestrial features of the Galapagos archipelago. In: Bensted-Smith R, ed. A Biodiversity Vision for the Galapagos Islands. Charles Darwin Foundation and World Wildlife Fund, Puerto Ayora, pp. 12-23.

Tylianakis JM, Didham RK, Bascompte J, Wardle DA (2008). Global change and species interactions in terrestrial ecosystems. Ecology Letters 11, 1351-63. 
Van der Pijl L (1982). Principles of Dispersal in Higher Plants. Springer-Verlag, Berlin.

Van Leeuwen J, Schäfer H, Van der Knaap W, Rittenour T, Björck S, Ammann B (2005). Native or introduced? Fossil pollen and spores may say. An example from the Azores Islands. Neobiota 6, 27-34.

Van Leeuwen JFN, Froyd CA, Van der Knaap WO, Coffey EE, Tye A, Willis KJ (2008). Fossil pollen as a guide to conservation in the Galapagos. Science 322, 1206.

Vander Wall SB (1994). Seed fate pathways of antelope bitterbrush: dispersal by seed-caching yellow Pine Chipmunks. Ecology 75, 1911-26.

Vander Zanden MJ, Olden JD, Gratton C (2006). Food-web approaches in restoration ecology. In: Falk DA, Palmer MA, Zedler L, eds. Foundations of Restoration Ecology. Island Press, Covelo, CA, pp. 165-89.

Verdú M, Traveset A (2004). Bridging meta-analysis and the comparative method: a test of seed size effect on germination after frugivores' gut passage. Oecologia 138, 414-18.

Wang BC, Smith TB (2002). Closing the seed dispersal loop.
Trends in Ecology and Evolution 17, 379-86.

Weeks A, Tye A (2009). Phylogeography of palo santo trees (Bursera graveolens and Bursera malacophylla; Burseraceae) in the Galápagos archipelago. Botanical Journal of the Linnean Society 161, 396-410.

Weiner J (1995). The Beak of the Finch: a Story of Evolution in our Time. Vintage Books, New York.

Wenny DG, Levey DJ (1998). Directed seed dispersal by bellbirds in a tropical cloud forest. Proceedings of the National Academy of Sciences of the United States of America 95, 6204-7.

White WM, McBirney AR, Duncan RA (1993). Petrology and geochemistry of the Galapagos islands: portrait of a pathological mantle plume. Journal of Geophysical Research-Solid Earth 98, 19533-63.

Wiggins IL, Porter DM (1971). Flora of the Galapagos Islands. Stanford University Press, Stanford, CA.

Williams PA, Karl BJ (1996). Fleshy fruits of indigenous and adventive plants in the diet of birds in forest remnants, Nelson, New Zealand. New Zealand Journal of Ecology 20, 127-45. 


\section{APPENDIX I}

References used to compile the plant-animal interactions described in Table 1.

\begin{tabular}{|c|c|c|}
\hline & Disperser & References \\
\hline \multirow[t]{6}{*}{ Mammalia } & Bos taurus & $1-4$ \\
\hline & Capra hircus & 5 \\
\hline & Sus scrofa & $1-3$ \\
\hline & Equus asinus & 6 \\
\hline & Rattus rattus & $7-12$ \\
\hline & Oryzomys galapagoensis & 13,14 \\
\hline \multirow[t]{16}{*}{ Aves } & Asio flammeus & 13 \\
\hline & Crotophaga ani & 12,15 \\
\hline & Mimus parvulus & $2,13,14,16-18$ \\
\hline & Zenaida galapagoensis & $2,13,19$ \\
\hline & Camarhynchus pallidus & $12,20,21$ \\
\hline & Camarhynchus parvulus & $10,12,20-22$ \\
\hline & Camarhynchus pauper & 22 \\
\hline & Camarhynchus psittacula & $10,12,20,21$ \\
\hline & Certhidia olivacea & 21 \\
\hline & Geospiza conirostris & $23-25$ \\
\hline & Geospiza difficilis & 24 \\
\hline & Geospiza fortis & $2,10,12,13,20-22,24-34$ \\
\hline & Geospiza fuliginosa & $10,12,20-22,24,28,29,31,34$ \\
\hline & Geospiza magnirostris & $12,13,20,21,24-26,28,30,32-34$ \\
\hline & Geospiza scandens & $14,20-24,28,29$ \\
\hline & Platyspiza crassirostris & $10,21,22,25,29$ \\
\hline \multirow[t]{4}{*}{ Reptilia } & Conolophus pallidus & 35 \\
\hline & Conolophus subcristatus & $2,14,20,36-38$ \\
\hline & Chelonoidis nigra & $3,6,10,14,37-42$ \\
\hline & Microlophus pacificus & 43 \\
\hline
\end{tabular}

1. Lawesson JE, Ortiz L (1994). Plantas Introducidas en las Islas Galápagos. In: Carrasco A, Valdebenito H, eds. Investigación botánica y manejo en Galápagos. Fundación Charles Darwin, Quito, pp. 224-35.

2. McMullen CK (1999). Flowering Plants of the Galápagos. Comstock Publishing Associates, Cornell.

3. Rentería JL, Buddenhagen C (2006). Invasive plants in the Scalesia pedunculata forest at Los Gemelos, Santa Cruz, Galápagos. Galápagos Research 64, 31-5.

4. Vries T, Tupiza A (1979). Dispersión y crecimiento del Guayabo (Psidium guajava) y la dinámica de población del Lechoso (Scalesia cordata) en Sierra Negra, Isla Isabela. Charles Darwin Research Station, Annual Re- port 1979. Charles Darwin Research Station, Puerto Ayora.

5. Thornton I (1971). Darwin's Islands: A Natural History of the Galápagos. Natural History Press, New York.

6. Fowler De Neira LE, Johnson MK (1985). Diets of giant tortoises and feral burros on Volcan Alcedo, Galapagos. The Journal of Wildlife Management 49, 165-9.

7. Clark DA (1980). Age- and sex-dependent foraging strategies of a small mammalian omnivore. Journal of Animal Ecology 49, 549-63.

8. Clark DA (1981). Foraging patterns of black rats across a desert-montane forest gradient in the Galápagos Islands. Biotropica 13, 182-94. 
9. Clark DA (1982). Foraging behavior of a vertebrate omnivore (Rattus rattus): meal structure, sampling, and diet breadth. Ecology 63, 763-72.

10. Rick CM, Bowman RI (1961). Galápagos tomatoes and tortoises. Evolution 15, 407-27.

11. Rick CM (1964). Some plant-animal relations on the Galápagos Islands. In: Bowman R, ed. Galápagos International Scientific Project. University of California Press, Berkeley, pp. 215-24.

12. Soria MC (2006). Avian seed dispersers of the invasive $R u$ bus niveus (Rosaceae) in Santa Cruz Island, Galápagos, Ecuador (MSc thesis). University of Missouri-St. Louis, St. Louis.

13. Grant PR, Smith JNM, Grant BR, Abbott IJ, Abbott LK (1975). Finch Numbers, owl predation and plant dispersal on Isla-Daphne-Major, Galápagos. Oecologia 19, 239 57.

14. Racine CH, Downhower JF (1974). Vegetative and reproductive strategies of Opuntia (Cactaceae) in the Galápagos Islands. Biotropica 6, 175-86.

15. Jara M (1995). Aspectos ecológicos, distribución y abundancia del garrapatero Crotophaga ani en el sur de la isla Isabela, Galápagos-Ecuador (BSc thesis). Departamento de Biologia, Pontificia Universidad Católica del Ecuador, Quito.

16. Grant PR, Grant N (1979). Breeding and feeding of Galápagos Mockingbirds, Nesomimus parvulus. The Auk 96, 723-36.

17. McMullen CK (2007). Pollination biology of the Galápagos endemic, Tournefortia rufo-sericea (Boraginaceae). Botanical Journal of the Linnean Society 153, 21-31.

18. Nuez F, Prohens J, Blanca JM (2004). Relationships origin, and diversity of Galápagos tomatoes: implications for the conservation of natural populations. American Journal of Botany 91, 86-99.

19. Grant PR, Grant KT (1979). Breeding and feeding ecology of the Galápagos Dove. The Condor 81, 397-403.

20. Bowman RI (1961). Morphological differentiation and adaptation in the Galápagos finches. University of California Publications in Zoology 58, 1-302.

21. Guerrero AM, Tye A (2009). Darwin's finches as seed predators and dispersers. The Wilson Journal of Ornithology 121, 752-64.

22. Gifford EW (1919). Expedition of the California Academy of Sciences to the Galápagos Islands, 1905-1906. XIII: field notes on the land birds of the Galápagos Islands and of Cocos Islands, Costa Rica. Proceedings of the California Academy of Sciences 2, 189-258.
23. Grant BR, Grant PR (1981). Exploitation of Opuntia cactus by birds on the Galápagos. Oecologia 49, 179-87.

24. Grant BR, Grant PR (1982). Niche shifts and competition in Darwin's finches Geospiza conirostris and congeners. Evolution 36, 637-57.

25. Lack D (1945). The Galápagos Finches (Geospizinae): a Study in Variation. California Academy of Sciences, San Francisco.

26. Beebe W (1924). Galápagos: World's End. Putnam's Sons, London.

27. Boag GT, Grant PR (1981). Intense natural selection in a population of Darwin's finches (Geospizinae) in the Galápagos. Science 214, 82-5.

28. Boag GT, Grant PR (1984). Darwin's finches (Geospiza) on isla Daphne Major, Galápagos: breeding and feeding ecology in a climatically variable environment. Ecological Monographs 54, 463-89.

29. Downhower JF, Racine CH (1976). Darwin's finches and Croton scouleri: an analysis of the consequences of seed predation. Biotropica 8, 66-70.

30. Grant PR (1981). The feeding of Darwin's finches on Tribulus cistoides (L.) seeds. Animal Behaviour 29, 78593.

31. Grant PR, Grant BR, Smith JNM, Abbott IJ, Abbott LK (1976). Darwin's finches: population variation and natural selection. Proceedings of the National Academy of Sciences of the United States of America 73, 257-61.

32. Lack D (1947). Darwin's Finches. Cambridge University Press, Cambridge.

33. Schluter D (1982). Distributions of Galápagos ground finches along an altitudinal gradient: the importance of food supply. Ecology 63, 1504-17.

34. Schluter D (1982). Seed and patch selection by Galápagos ground finches: relation to foraging efficiency and foodsupply. Ecology 63, 1106-20.

35. Christian KA, Tracy CR (1985). Physical and biotic determinants of space utilization by the Galápagos land iguana (Conolophus pallidus). Oecologia 66, 132-40.

36. Carpenter C (1969). Behavioral and ecological notes on the Galápagos land iguana. Herpetologica 25, 155-64.

37. Darwin C (1989). The Voyage of the Beagle: Charles Darwin's Journal of Researches. Penguin Classics, London.

38. Estupiñan S, Mauchamp A (1995). Interacción plantaanimal en la dispersión de Opuntia de Galápagos (Report). Charles Darwin Foundation, Puerto Ayora.

39.Albuja L (1972). Los Galápagos (BSc thesis). Departamento de Biologia, Pontificia Universidad Católica del Ecuador, Quito. 
40.Cayot L (1987). Ecology of Giant Tortoises (Geochelone elephantopus) in the Galápagos Islands. The Graduate School of Syracuse University, New York.

41.Stewart A (1911). Expedition of the California Academy of Sciences to the Galápagos Islands, 1905-1906. II: a botanical survey of the Galápagos Islands. Proceedings of the California Academy of Sciences 1, 7-288.
42. Gibbs JP, Marquez C, Sterling EJ (2008). The role of endangered species reintroduction in ecosystem restoration: tortoise-cactus interactions on Española Island, Galápagos. Restoration Ecology 16, 88-93.

43. Schluter D (1984). Body size, prey size and herbivory in the Galápagos lava lizard, Tropidurus. Oikos 43, 291300 . 